\title{
Futbol Kulüpleri İçin Hedef Kitle Olan Kadınların Stadyumlarda Maç İzleme Tutumlarını İncelemeye Yönelik Ampirik Bir Araştırma
}

\author{
Fahri APAYDIN 1 \\ Caner GÍRAY ${ }^{2}$ \\ İpek AMANVERMEZ ${ }^{3}$
}

\begin{abstract}
Özet
Büyük bir endüstri olan futbol, kulüplerce bir eğlence sektörü olarak yürütülmekte ve bu sektörü düzenleyen üst kurul olarak ise Türkiye Futbol Federasyonu bulunmaktadır. Keşifsel bir araştırma olan bu çalışmada Federasyon'un futbol kulüplerine yaptırım olarak uyguladığı seyircisiz müsabaka oynama cezası yerine stadyumlara ücretsiz olarak kadın ve çocuk seyirci almanın kadınlar üzerindeki tutundurma etkisi araştırmanın birincil amacı olarak incelenmektedir. Araştırmanın ikincil amacı olarak ise kadınların futbol müsabakalarına tutumları incelenmektedir. Anket yöntemiyle elde edilen verilerin analiz sonuçlarına göre Federasyon'un uygulamasının kadınlar üzerinde olumlu tutundurma etkisi yapmaktadır. Ayrıca araştırma sonuçlarına göre kadınların futbol izlemek için stadyumlara gitmelerinde etkili olan temel bazı faktörler ise taraftar olma güdüsü, bilet fiyatları, boş zaman bulma, güvenlik kaygısı, sosyal ve arkadaş çevresi ve stadyumların fiziki yapısıdır.
\end{abstract}

Anahtar kelimler: Futbol, Kadın Taraftarlar, Türkiye Futbol Federasyonu, Tutundurma, Eğlence Endüstrisi

\section{An Empirical Research Analyzing the Attitudes of Women towards Watching Football Games in Stadiums Who are in Target Group of Football Clubs}

\begin{abstract}
Football, which is a huge entertainment industry, is managed by the clubs and, Turkish Football Federation exists as a higher coordination institution. In this exploratory study, the primary aim is to examine the promotional effect of the application of Federation in which it permits the clubs to accept women and children under a certain age to the stadiums free of charge as audience instead of punishing the clubs by letting them play matches in their stadiums without audience. The secondary aim of the study is to examine the attitudes of women towards football matches. According to the results of the data obtained using questionnaire forms, the application creates positive promotional effects for women. In addition, the results also indicate that the factors that affect women's decision whether to go to stadiums to watch the games are motivation of being a spectator, game fees, leisure time, security, social environment and friends.
\end{abstract}

Keywords: Football, Women Audience, Turkish Football Federation, Promotion, Entertainment Industry

\footnotetext{
${ }^{1}$ Doç. Dr., Yalova Üniversitesi, İktisadi ve İdari Bilimler Fakültesi, İşletme Bölümü, fapaydin1@yahoo.co

${ }^{2}$ Dr., Dr., canergiray@ hotmail.com

3 ipekperay@gmail.com
} 
Yalova Sosyal Bilimler Dergisi

\section{Giriş}

İnsanlar eğlenmek, hoş vakit geçirmek, para kazanmak, kendini geliştirmek, kültürler ve toplumlar arası diyaloğu geliştirmek ve diğer başka nedenlerle çeşitli spor faaliyetlerine katılmaktadırlar. Dünyada en yaygın ve kapsamlı ve aynı zamanda ticari olarak da en hacimli faaliyetlerin yapıldığ spor dallarının biri ise futboldur. Dolayısıyla da futbol gerek dünyada gerekse Türkiye'de büyük bir endüstri haline gelmiştir ve futbol endüstrisi gittikçe de büyümektedir (Mehus, 2005: 334). Çok büyük kitleler futbolla aktif ya da pasif olarak ilgilidirler. Futbol eylemlerini yöneterek, futbol oynayarak, futbol müsabakalarını izlemek için stadyumlara giderek, futbol ürünlerini tüketerek (televizyon kanalı abonesi olarak, spor gazetesi alarak, vs.), destek hizmetleri (kamp alanları sunarak, menejerlik yaparak) sunarak, futbol yorumculuğu yaparak, futbolcu eğitmenliği yaparak ve benzeri başka eylemleri yaparak milyonlarca kişi futbol endüstrisinde aktif olarak rol oynamaktadırlar. Çok sayıda insan ise çeşitli nedenlerle aktif olmasa da pasif olarak futbola ilgi duymaktadırlar. Bunlardan bazıları futbol müsabakalarının sadece sonuçlarını takip etmekte, bazıları ise çevresindeki insanlarla taraftar olduğu takımın performansı ve eylemleri ile ilgili iletişim kurmaktadırlar (Berument ve Yücel, 2005: 844). Futbol endüstrisinden para kazanan insanlar ise pasif olan bu kişileri aktif olarak futbol endüstrisine çekme çabaları gütmektedirler.

Dünyada futbol endüstrisini düzenlemek üzere uluslararası çeşitli kurumlar (UEFA, FIFA gibi) oluşturulmuştur. Bu kurumlar üst kurul olarak rol oynamakta ve ülkeler bazında da kurullar oluşmasını sağlayarak ülke içindeki futbol endüstrisinin uluslararası normalara uygun olarak düzenlemesini zorunlu k1lmaktadırlar. $\mathrm{Bu}$ kapsamda Türkiye'de de futbol endüstrisini düzenleme görevini üstlenen kurul Türkiye Futbol Federasyonu'dur (TFF). TFF, Türkiye'de futbol endüstrisinin uluslararası normlara uygun olarak işlemesi için futbol endüstrisinin en önemli aktörleri olan futbol kulüplerinin faaliyetlerini takip etmekte ve futbol müsabakalarını organize ederek norm dışına çıkılması durumda ise kulüplere bir kısmı ekonomik bir kısmı ise cezai olmak üzere çeşitli yaptırımlar uygulamaktadırlar. Bu şekilde TFF futbol endüstrisinin etkin olarak işlemesini sağlamaya çalışmanın yanında aldığı kararlarla gelişmesine de çalışmaktadır.

TFF, mesübakalar esnasında belirlediği bazı kurallara kulüplerin uymaması durumunda müsabakaların "seyircisiz oynanması" cezasını vermektedir. Türkiye'de son zamanlarda futbol endüstrisindeki bir takım olumsuz gelişmeler ve başka nedenlerden dolayı insanların futbola ilgilisi azalmakta ya da futbol eylemelerine aktif olarak katılmaktan kaçınmaktadırlar. Bu ise endüstinin gelişmesini yavaşlatmaktadır ve endüstride faaliyet gösteren işletmelerin ve özellikle de futbol kulüplerinin gelirlerinde kayıplar oluşturmaktadır. TFF, aldığı bir kararla, 30 Eylül- 3 Ekim 2011 tarihlerinde oynanan Spor Toto Süper Ligi'nin 5.hafta maçlarının seyircisiz oynanması yerine "Kadınların ve 16 yaş altı çocukların müsabakalara ücretsiz girme" projesini uygulamaya koymuştur (http://www.futbolekonomi.com). Bu kararla amaç "seyircisiz maç oynama cezaları" yerine kadınların ve çocukların stadyumlara çekilerek futbola ilgilerini artırmaktır. $\mathrm{Bu}$ uygulama araştırmanın bu kısmından sonra "TFF'nin 
Yalova Sosyal Bilimler Dergisi

uygulaması" olarak geçmektedir. Dünya'da da büyük ilgi uyandıran bu uygulamaya çok sayıda çocuk ve kadın ilgi göstermiş ve stadyumlarda futbol müsebakası izlemişlerdir.

$\mathrm{Bu}$ uygulamanın psikolojik ve sosyolojik etkilerinin yanında pazarlama açısından da etkileri bulunmaktadır. Milyonlarca kişinin daha önce belirtildiği gibi aktif ya da pasif olarak ilgi duyduğu ve binlerce işletme ya da bireylerin gelir elde ettiği futbol endüstrisinde gerçekleşen gelişmelerin akademisyenlerce incelenmesi gerekmektedir. $\mathrm{Bu}$ amaçla keşifsel bir araştırma olan bu çalışmada TFF'nin uygulamasının endüstrideki etkisi incelenmektedir. $\mathrm{Bu}$ uygulamanın futbol endüstrisinde çok sayıda etkilerinin olması kaçınılmazdır (örneğin forma satışlarındaki değişim). Ancak bu çalışma TFF'nin uygulamasının kadınların futbol müsabakalarına olan tutum ve ilgilerini ne yönde etkilediğini incelemektedir. Uygulamanın tutundurma etkisini de inceleyen bu araştırmanın gerek literatüre gerekse futbol endüstrisine katkıda bulunacağına inanılmaktadır ve uygulamanın yeni olması nedeniyle bu konunun daha önce araştırılmamış olduğuna inanılmaktadır. Bu ise araştırmanın orjinal bir çalışma olmasını sağlamaktadır.

\section{Literatür Taraması}

İnsanların ihtiyaçları arasında önemli bir tanesi de eğlenmek ve keyif almaktır. İnsanlar çeşitli faaliyetler yapıp eğlenerek ve keyif alarak bu ihtiyaçlarını gidermektedirler. İnsanlar aynı zamanda gerek sosyalleşmek gerekse boş zamanlarını değerlendirmek amacıyla da çeşitli faaliyetler yapmaktadırlar (Gwinner ve Swanson:276; Richardson ve O’Dwyer, 2003: 43; Lough ve Kim, 2004; 36). Bu ihtiyaçları tatmin eden faaliyetlerden bir tanesi ise stadyumlara giderek futbol müsabakası seyretmektir. Bu ihtiyacını gidermek amacıyla çok sayıda insan harcama yapmaktadır. İnsanların bu ihtiyacını gidermek için ise çok sayıda işletmeler ki bunların başında futbol kulüpleri gelmektedir çeşitli faaliyetler yürütmektedirler.

Futbol birçok insan için seyir zevki olan ve şova yönelik bir spor dalı olduğundan insanların ilgisini çekmektedir. Aynı zamanda yarışma özelliğinin olması da insanların taraftar olduğu takımın galip gelmesi durumunda keyif almalarına neden olmaktadır (James ve Ross, 2004:18; Clowes ve Tapp, 2003: 58; Yoshida vd., 2013: 69). Bu nedenle çok sayıda insan futbol endüstrisi tarafindan geliştirilen çok sayıda farklı kategorideki futbol müsabakalarını izlemek için stadyumlara gelmektedir. $\mathrm{Bu}$ kategorilerden bazıları ülkeler arasında oynanan ve insanların milliyetçilik duygusunu etkileyen milli maçlar ve "derbi" olarak adlandırılan yüksek düzeyde performans gösteren takımlar arasında oynanan müsabakalar da bulunmaktadır (Kenneth vd., 1999). Bazı araştırmalarda spor müsabakalarını izleme nedenleri olarak aşağıdaki unsurlar belirlenmiştir (Mehus, 2005: 334):

a- Haz duymak,

b- Gerilim yaşamak, 
Yalova Sosyal Bilimler Dergisi

c- Aynı düşüncede olan insanlarla beraber olmak,

d- Heyecan duymak,

e- Başarı duygusu yaşamaktır.

Çok farklı demografik özelliğe sahip tüketiciler futbola ilgi duymaktadır. Demografik özelliklerden biri olan yaş açısından değerlendirildiğinde hemen her yaşta insan futbola değişik düzeyde ilgi duymakta ve ilgi düzeylerine bağlı olarak da futbol endüstrinde çeşitli amaçlarla harcama yapmaktadırlar (Türkmen vd., 1998: 26; Shank, 2003; Wann ve Pierce, 2003: 366). Farklı gelir düzeyi, eğitim düzeyi ve mesleklere sahip çok farklı özelliklere sahip kişiler de yine farklı düzeylerde bu endüstri dalında harcama yapmaktadırlar. Demografik özelliklerden bir diğeri ise cinsiyettir. Türkiye'de genelde erkek tüketicilerin futbola daha fazla ilgi duyduğu görülmekle beraber özellikle son zamanlarda kadınlarında futbola ilgileri artmıştır. Fakat yine de erkeklerin ilgilenim düzeyleri daha fazla olduğundan bu endüstride daha fazla harcama yapma eğiliminde oldukları söylenebilir.

Tüketicilerin ilgi düzeyleri yukarıda belirtilen unsurlar vasitasıyla futbol takımlarının gelir yaratmasına katkıda bulunmaktadırlar. Bu gelirlerin içerisinde ise stadyumlara müsabaka izlemek için giden futbol izleyicilerinin bilet almak için ödedikleri para önemli yer tutmaktadır (Ross, 2006: 24; Hill ve Green, 2000: 146). Bu nedenle de futbol kulüpleri futbol izleyicilerini stadyumlara çekebilmek için yoğun çaba sarf etmektedirler.

Tutundurma pazarlama faaliyetlerinin önemli unsurlarından biridir. Her ürün ve hizmet pazarlamasında olduğu gibi spor pazarlamasında da yaygın olarak kullanılmaktadır. En başta gelen işlevi tüketicilerin ihtiyaçlarını gidermek üzere geliştirilen hizmet ve ürünlerin onlar tarafından satın alınmasını sağlamaktır. Bunun yanında tüketicilerin satın almalarını sürekli hale getirmek ve artırmak da amaçları arasındadır. $\mathrm{Bu}$ amaca yönelik olarak işletmeler tarafından çeşitli faaliyetler yürütülmektedir. Reklam, kişisel satış, halkla ilişkiler, satış geliştirme ve fuar ve sergiler temel tutundurma faaliyetlerindendir (Kotler, 2008).

Satış geliştirme, "kişisel satış, reklam, halkla ilişkiler ve doğrudan pazarlama çabaları dişında kalan, genellikle sürekli olarak yürütülmeyen, fuarlara katılma, sergiler vb. devamlılığı olmayan diğer satış çabalarıdır" (Mucuk, 2010: 209) şeklinde açıklanmaktadır. Satış geliştirmenin işlevlerinden biri de tüketicilerin tutumlarını değiştirerek ürün ya da hizmetlerin daha çok kullanılmasını ve satın alınmasını sağlamanın yanında bir hizmetle ilgili çeşitli yöntemlerle satış geliştirme uygulanmaktadır. 2 Adet üründen alana üçüncünün ya da deneme/tanıtma amaçlı ürün ya da hizmetlerin ücretsiz verilmesi ya da kullandırılması satış geliştirmeye örnek olarak verilebilir. $\mathrm{Bu}$ araştırmada TFF'nin uygulaması da satış geliştirme olarak değerlendirilmektedir. 
Yalova Sosyal Bilimler Dergisi

\section{Yöntem ve Bulgular}

Araştırmada elde edilen verilere bağlı olarak yapılan analizlere ve testlere bu bölümde değinilmektedir. Bu bölümde araştırmada kullanılan örneklemle ilgili temel özellikler, ölçek geliştirme süreci, veri toplama süreci, ölçekle ilgili yapılan güvenirlik analizi, faktör analizi, literatür kısmına bağlı olarak oluşturulan hipotezlerin test edilmesi için uygulanan korelasyon analizleri ve regresyon analizi bulunmaktadır.

\subsection{Anakütle ve Örnekleme}

Araştırmanın anakütlesini Türkiye Futbol Federasyonu'nca, kulüplere verilen seyircisiz müsabaka yapma cezası yerine kadınların ve çocukların müsabakalara alınması uygulamasından yaralananarak ceza almış bir takımın maçını (Fenerbahçe) bayların olmadığı bir ortamda izlemeye gelerek bu uygulamadan yararlanan kadınlar oluşturmaktadır. Sadece kadın ve çocuk izleyicilerin olduğu 2 adet Fenerbahçe Şükrü Saraçoğlu'nda oynan müsabakalara gidilerek orada bulunan rastgele seçilmiş 210 adet kadınlar araştırmanın örneklemini oluşturmaktadır. Anket yöntemiyle elde edilen veriler SPSS programına girilmiş ve çeşitli analizler yapılmıştır.

\subsection{Anket Ölçeklerinin Oluşturulması, Faktör Analizi ve Ölçeklerin Güvenirliği}

Ankette futbol seyircilerinin futbol karşılaşmalarına gitme güdülerini kapsayacak 47 adet ifade geliştirilerek kullanılmıştır. İfadeler 5'li Likert tipi ölçeğe dönüştürülmüş ve örneklem kitlesindeki kadınlardan bu ifadelere 5 (Çok Yüksek) olmak üzere ve 1 (Çok Düşük) olmak üzere ne oranda katıldıklarını belirtmeleri istenmiştir. Araştırmanın son kısmında ankette kullanılan ifadeler bulunmaktadır. 41 ve 42. ifadeler olumsuz olduğu için SPSS programına veriler girilirken 1'ler 5 ve 5'ler 1 olarak ters girilmiştir.

Anketle elde edilen verilere keşifsel faktör analizleri uygulanmıştır. "Verimax" yöntemiyle rotasyon uygulayarak faktörlerin daha net olarak ayrışması hedeflenmiştir. Eigien değeri 1'den fazla olan ifadeler analizlere dâhil edilmiştir. İlk analizde 11 faktör çıkmış ve varyansın \%75'1 açıklanmıştır. Ancak boş zamanı ölçmek amacıyla sorulan sorulardan biri tek başına farklı bir faktör olarak ortaya çıkmıştır. Sorulardan birinin ise iki farklı faktöre yüklenme eğiliminde olduğu görülmüş ve başka iki sorunun ise faktör yüklerinin eksi olarak bir faktöre yüklendiği belirlenmiştir. Bu nedenle bahsedilen bu son üç soru analizlerden çıkartılarak ölçek yeniden faktör analizine taabi tutulmuştur. Yeni faktör analizinde ise açıklanan varyans \%71 olarak gerçekleşmiştir. İki soru düşük faktör yüküyle ayrı bir faktör oluşturduklarından bu sorular da analizlerden çıkartılmış ve yeniden faktör analizi yapılmıştır. Son faktör analizinde ise beklenen temel fakörlerin ortaya çıktığı ve açıklanan varyansın ise \%73'e çıktığı belirlenmiştir. $\mathrm{Bu}$ süreçte açıklanan varyansta dikkate değer ölçüde azalma olmaması ve faktörlerin net olarak ayrışması ölçeğin tutarlılığını göstermektedir. 
Cronbach's alpha katsayısı ile ölçekte kullanılan soruların güvenirlikleri ölçülmüştür. Ankette 3 ifade ile kadınların bilet fiyatları hakkındaki tutumları ölçülmüş ve güvenirlik katsayısı 0.70 ve açıkladığ 1 varyans 4,85 olarak bulunmuştur. Kadınların stadyumların fiziki durumu hakkındaki düşüncelerini öğrenmek amacıyla da 3 ifade kullanılmış ve güvenirlik katsayısı 0.79 ve açıkladığı varyans 5,79 olarak bulunmuştur. Kadınların arkadaşlarından etkilenerek maça gidip gitmediğini ölçmek amacıyla 3 ifade kullanılmış ve güvenirlik katsayısı 0.82 ve açıkladığı varyans 5,42 olarak bulunmuştur. Arkadaşlar dışında kadınların sosyal çevresindeki insanların maçlara gitmeleri konusundaki görüşlerini ne ölçüde önemsediklerini ölçmek amacıyla da 3 ifade kullanılmış ve bunların güvenirlik katsayısı 0.87 ve açıkladığı varyans 7,24 olarak bulunmuştur. Kadınların maçlara gitmelerinde güvenlik konusuyla ilgili 3 ve bay seyircilerin maçlardaki tutumları ile ilgili 3 ifade kullanılmıştır. Bunların ayrı faktörlere yüklenmesi beklenmesine rağmen tek bir faktöre yüklendikleri görülmüş ve güvenirlik katsayısı ise 0.80 ve açıkladığı varyans 7,58 olarak bulunmuştur. Futbol federasyonunun seyircisiz müsabaka uygulamasına yönelik kadınların tutumlarını ölçmek için 6 ifade kullanılmış ve güvenirlik katsayısı 0.87 ve açıkladığı varyans 8,78 olarak bulunmuştur. Kadınların futbol müsabakalarına gitmek için boş zaman bulup bulamadıklarını ölçmek amacıyla 4 ifade kullanılmış ve güvenirlik katsayısı 0.75 ve açıkladığı varyans 5,07 olarak bulunmuştur. Kadınların maça gitmelerinde taraftar olma güdülerini ölçmek amacıyla 3 ifade ve futbola ilgilerini ölçmek amacıyla 3 ifade kullanılmıştır. Bu 6 ifade de tek bir faktöre yüklenmiş ve güvenirlik katsayısı 0.88 ve açıklanan varyans 11,45 olarak bulunmuştur. Futbol Federasyonu'nun bu uygulamasının kadınlara yönelik tutundurma etkisini ölçmek amacıyla 6 ifade kullanılmıştır ve bunların güvenirlik katsayısı 0.95 ve açıklanan varyans 8,78 olarak bulunmuştur. Faktörlerin güvenirlik katsayısı kabul edilen 0.70 'den fazla olması nedeniyle ölçek güvenilir olarak görülmektedir. Bu bulgular Tablo 1'de görülmektedir.

\section{Tablo 1: Faktör Analizi Tablosu}

\begin{tabular}{|l|c|c|c|c|c|c|c|c|c|}
\hline \multirow{2}{*}{ Sorular } & \multicolumn{9}{|c|}{ Faktörler } \\
\cline { 2 - 8 } 1 & 1 & 2 & 3 & 4 & 5 & 6 & 7 & 8 & 9 \\
2 & 0,81 & & & & & & & & \\
3 & 0,79 & & & & & & & & \\
4 & 0,63 & & & & & & & & \\
5 & & 0,80 & & & & & & & \\
6 & & 0,81 & & & & & & & \\
7 & & 0,63 & & & & & & & \\
8 & & 0,77 & & & & & & & \\
9 & & 0,78 & & & & & & & \\
10 & & & 0,78 & & & & & & \\
11 & & & 0,66 & & & & & & \\
12 & & & 0,82 & & & & & & \\
13 & & & & 0,59 & & & & & \\
15 & & & & 0,65 & & & & & \\
16 & & & & 0,62 & & & & & \\
18 & & & & 0,73 & & & & & \\
\hline
\end{tabular}


Yalova Sosyal Bilimler Dergisi

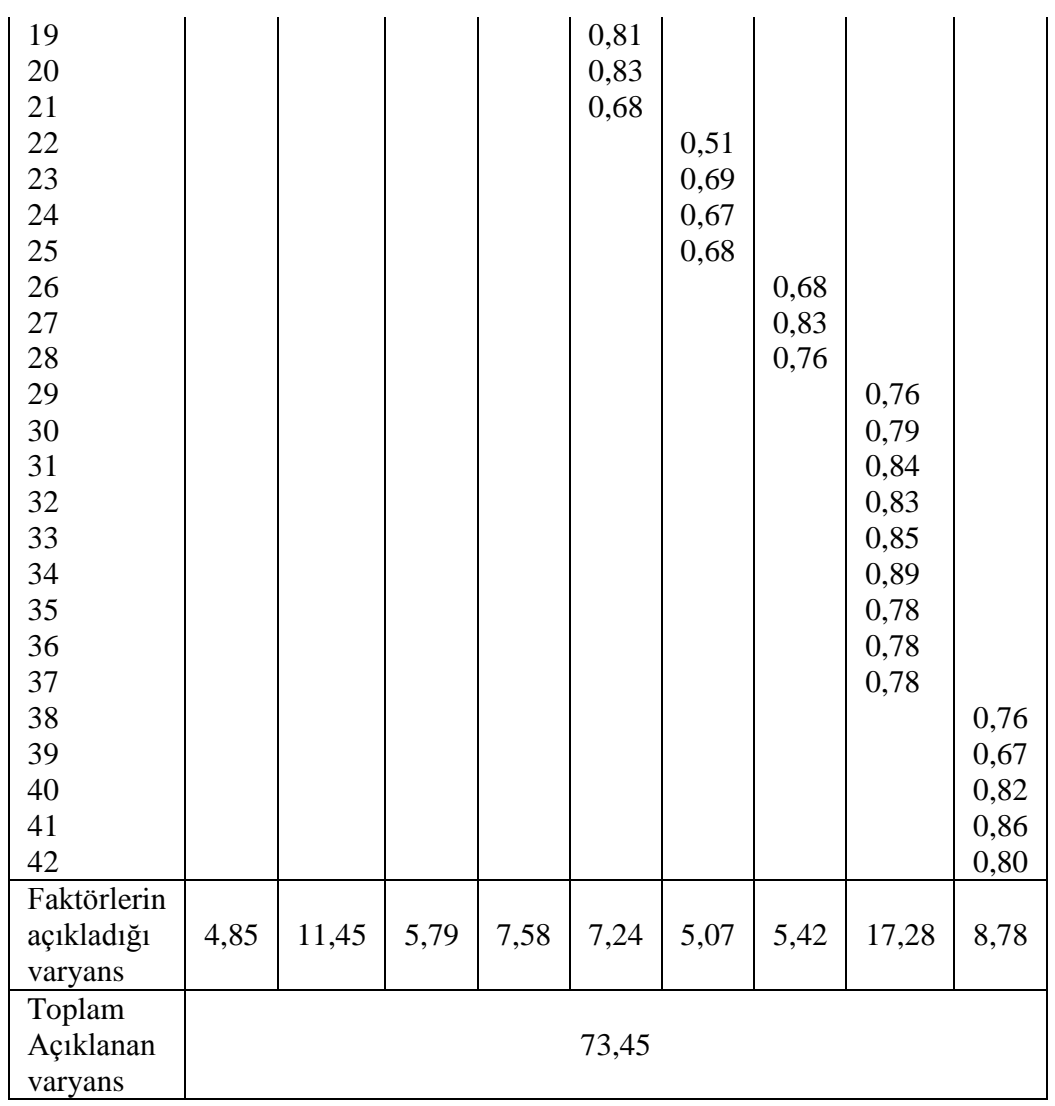

Değişkenler arasındaki korelasyon Tablo 2'de görülmektedir. Buna göre bilet fiyatları ile sosyal çevre arasında düşük düzeyde korelasyon bulunmaktadır. Fiyat ile diğer değişkenler arasında ise korelasyon bulunmamaktadır. Taraftar olma güdüsüyle uygulamaya karşı tutum dışındaki diğer değişkenler arasında da genelde düşük düzeyde korelasyon bulunmaktadır. Ancak taraftar olma ile stadyumların fiziki yapısı, güvenlik ve sosyal çevre arasındaki korelasyon eksi yöndedir. Ayrıca taraftar olma güdüsüyle boş zaman arasındaki korelasyon orta düzeydedir. Stadyumların fiziki yapısıyla güvenlik ve sosyal çevre arasında düşük düzeyde korelasyon bulunmaktadır. Stadyumların fiziki yapısıyla arkadaş etkisi ve uygulamaya karşı tutum arasında korelasyon bulunmaktadır. Güvenlik ile sosyal çevre arasında orta düzeye yakın korelasyon bulunmaktadır. Diğer taraftan güvenlik ile boş zaman arasında negatif bir korelasyon bulunmakatdır. Güvenlikle arkadaş etkisi, tutundurma etkisi ve uygulamaya karşı tutum arasında düşük düzeyde korelasyon bulunmaktadır. Sosyal çevre ile boş zaman ve tutundurma arasında negatif bir korelasyon bulunmaktadır. Boş zamanla arkadaş etkisi ve tutundurma etkisi arasında zayıf düzeyde korelasyon bulunmaktadır. Arkadaş etkisiyle tutundurma etkisi arasında orta düzeyde ve uygulamaya karşı tutum arasında zayıf korelasyon bulunmaktadır. Tutundurma etkisiyle uygulamaya karşı tutum arasında zayıf düzeyde korelasyon bulunmaktadır. 
Yalova Sosyal Bilimler Dergisi

Tablo 2: Korelasyon Tablosu

\begin{tabular}{|l|c|c|c|c|c|c|c|c|c|c|}
\hline & Ort. & $\begin{array}{c}\text { Std. } \\
\text { Sap. }\end{array}$ & 1 & 2 & 3 & 4 & 5 & 6 & 7 & 8 \\
\hline 1 bilet fiyatları & 3,45 & 0,93 & & & & & & & & \\
\hline 2 taraftar olma & 3,97 & 0,85 & 0,10 & & & & & & & \\
\hline 3 stad. fiziki yap. & 2,50 & 1,00 & 0,12 &,$- 355^{* *}$ & & & & & & \\
\hline 4 güvenlik & 3,75 & 0,86 & $-0,05$ &,$- 270^{* *}$ &, $282^{* *}$ & & & & & \\
\hline 5 sosyal çevre & 2,14 & 1,11 &, $288^{* *}$ &,$- 315^{* *}$ &, $362^{* *}$ & 0,13 & & & & \\
\hline 6 boş zaman & 3,82 & 0,83 & 0,04 &, $530^{* *}$ &,$- 331^{* *}$ &,$- 238^{* *}$ &,$- 355^{* *}$ & & & \\
\hline 7 arkadaş etkisi & 4,05 & 0,77 & 0,01 &, $154^{*}$ & 0,01 &, $205^{* *}$ & $-0,01$ &, $160^{*}$ & & \\
\hline 8 tutundurma et. & 3,44 & 0,91 & 0,00 &, $355^{* *}$ &,$- 229^{* *}$ &, $222^{* *}$ &,$- 227^{* *}$ &, $293^{* *}$ &, $516^{* *}$ & \\
\hline 9 uyg. tutum & 3,52 & 1,14 & $-0,10$ & $-0,03$ & 0,00 &, $234^{* *}$ & $-0,04$ & 0,00 &, $280^{* *}$ &, $325^{* *}$ \\
\hline
\end{tabular}
**.0.01 düzeyinde anlaml1 (2-kuyruk).
*. 0.05 düzeyinde anlamlı (2-kuyruk).

Tablo 3'de regrasyon analizi sonuçları görülmektedir ve sonuçlara göre regrasyon modeli anlamlı çıkmaktadır $(p<0,001)$. Sonuçlar bağımlı değişken olan futbol federasyonunun uygulamasının tutundurmaya etkisindeki varyansın \% 45'ini 9 faktör açıklamaktadır. Bu oranın oldukça yüksek olduğu görülmektedir. Modelde bağımsız değişkenlerden taraftar olma, güvenlik, arkadaş etkisi, fiziki yapı ve uygulamaya karşı tutum bağımlı değişkenden kabul edilen anlamlılık düzeyi olan $\mathrm{p}<0,05$ 'den yüksek olduğundan anlamlı olarak kabul edilmektedir. Bunlardan taraftar olma değişkeninin anlamlılık düzeyi $\mathrm{p}<0,001$ ve beta katsay1sı 0,23 'dür. Güvenlik değişkeninin anlamlılık düzeyi $\mathrm{p}<0,001$ ve beta katsayısı 0,25 'dir. Arkadaş etkisi değişkeninin anlamlılık düzeyi $\mathrm{p}<0,001$ ve beta katsayısı 0,37 'dir. Fiziki yapı değişkeninin anlamlılık düzeyi $\mathrm{p}<0,01$ ve beta katsayısı $-0,16$ 'dır. Uygulamaya karşı tutum değişkeninin anlamlılık düzeyi $\mathrm{p}<0,001$ ve beta katsayısı ise 0,17 'dir. Diğer değişkenlerin (boş zaman, sosyal çevre ve bilet fiyatları) ise modelde anlamlı olmadığı görülmektedir.

\section{Tablo 3: Regrasyon Analizi}

\begin{tabular}{|c|c|c|c|}
\hline Bağımsız Değişkenler & Stand. Beta kat. & t- değeri & Anlamlılık \\
\hline Sabit & & $-1,49$ & 0,14 \\
\hline taraftar olma & 0,23 & 3,61 & 0,00 \\
\hline boş zaman & 0,08 & 1,19 & 0,24 \\
\hline güvenlik & 0,25 & 4,32 & 0,00 \\
\hline sosyal çevre & $-0,10$ & $-1,70$ & 0,09 \\
\hline arkadaş etkisi & 0,37 & 6,58 & 0,00 \\
\hline fiziki yapı & $-0,16$ & $-2,78$ & 0,01 \\
\hline bilet fiyatları & 0,05 & 0,92 & 0,36 \\
\hline uygulamaya tutum & 0,17 & 3,09 & 0,00 \\
\hline \multicolumn{4}{|c|}{ Model (bağımlı değişken TFF’nin uygulamasının tutundurma etkisi) } \\
\hline Uyarlanmış R Kare & Anlamlılık & F Değeri & Serbestlik dereces \\
\hline 0.45 & 0.01 & 22.90 & $08 / 21$ \\
\hline
\end{tabular}


Yalova Sosyal Bilimler Dergisi

\section{Sonuç ve Öneriler}

Futbol dünyada olduğu gibi ülkemizde de büyük bir endüstridir ve çok sayıda işletme ve bireyler bu endüstri ile ilgili faaliyetler yürüterek kar elde etmeye çalışmaktadırlar. Aynı zamanda çok sayıda tüketici de eğlence endüstrisinin bir parçası olan bu endüstri dalında üretilen ürün ve hizmetleri tüketmektedir. Bu nedenle pazarlama alanında akademik faaliyet gösteren akademisyenlerin bu endüstrideki dinamikleri ve faaliyetleri incelemesi gerekmektedir. Türkiye Futbol Federasyonu'nun kulüplere verdiği seyircisiz müsabaka oynama cezası yerine cezalı müsabakalarda stadyumlara ücretsiz olarak kadın ve çocuk seyircilerin alınması uygulamasının endüstride büyük etkiler doğuracağ 1 görülmektedir. Keşifsel bir araştırma olan bu çalışmada bu etkilerden bazılarının neler olabileceğini incelenmektedir. Anket yöntemiyle elde edilen verilerin analizleri sonucunda endüstrinin daha da gelişmesine katkıda bulunacağı düşünülen bazı veriler elde edilmiştir.

Araştırmada kadın taraftarların stadyumda futbol müsabakalarına ilgilerini ve tutumlarını etkilyebilecek değişkenler olarak bilet fiyatları, taraftar olma, stadların fiziki yapısı, güvenlik, sosyal çevre, boş zaman ve arkadaş etkisi faktörleri ile TFF'nin uygulamasının tutundurma etkisi ve kadınların müsabakaya tutumları incelenmiştir. $\mathrm{Bu}$ unsurların faktör analizinde de görüldüğü gibi oldukça yüksek bir varyans açıkladığı görülmekte olup araştırmada kullanılan ölçeğin tutarlı olduğunu göstermektedir.

Korelasyon tablosu incelendiğinde oldukça dikkat çekici ilginç sonuçlar görülmektedir. Buna göre bilet fiyatlarının ortalamasına bakıldığında düşük miktarda ortalamadan yüksek çıktığı görülmektedir. Bu da bilet fiyatlarının kadın taraftarlarca yüksek bulunmadığını göstermektedir. Sosyal çevre ile taraftar olma arasında orta düzeyde korelasyon bulunmaktadır. Sosyal çevre ile kadınların arkadaş grupları dışındaki çevresinde bulunan kendilerine sosyal baskı kurabilecek kişiler kasdedilmektedir ve bunların etkisi olumsuz olarak sorulmuş ve değerler ortalamadan düşük çıkmıştır. $\mathrm{Bu}$ da kadınların stadyuma gitmelerinde sosyal çevrenin olumsuz etkisi olmadığını göstermektedir. Sosyal çevre ile taraftar olma arasında orta düzeye yakın negatif bir korelasyon bulunmaktadır. Bu da kadınların taraftar olma güdülerini sosyal çevrenin olumsuz etkilediğini göstermektedir. Sosyal çevre ile güvenlik arasında ise orta düzeye yakın pozitif bir ilişki bulunmaktadır ki bu da kadınların stadyumlardaki güvenlikle ilgili kaygılarını sosyal çevrenin artırmasına neden olmaktadır. Boş zaman ile taraftar olma arasında orta düzeyde olumlu korelasyon bulunmaktadır. Bu da boş zamanı olan kadınların taraftar olma eğilimlerinin yüksek olduğunu göstermektedir. Taraftar olmayı yine arkadaşlar da olumlu yönde etkilemektedir. Ayrıca TFF'nin uygulamasının kadınların taraftar olma eğilimini olumlu yönde etkilediği gerek korelasyon analizinde gerekse regrasyon analizinde görülmektedir. $\mathrm{Bu}$ da bu uygulamanın kadın taraftarlara tutundurma etkisi yarattığını göstermektedir.

Kurulan regrasyon modelinde ise bağımlı değişken olarak TFF'nin uygulaması alınmış ve fiyat, taraftar olma, boş zaman, güvenlik, sosyal çevre, arkadaş etkisi, stadyumların fiziki yapısı ve kadınların uygulamaya karşı tutumları ise bağımsız 
değişken olarak kullanılmıştır. Regrasyon analizi sonucuna göre kadınlar taraftar olma eğilimi göstermektedirler. Ayrıca güvenlik kaygısı onların stadyuma gelip gelmemelerinde önemli bir etkendir. Kadınların TFF'nin uygulamasına karşı olumlu tutuma sahip olduğu görülmektedir. $\mathrm{Bu}$ nedenle bu uygulamanın devam etmesinin daha çok kadının stadyumlara gitmesine neden olacağına inanılmaktadır. Ayrıca bulgularda kadınlar Fenerbahçe stadyumunun konforlu olduğuna ve burada maç seyretmenin keyifli olduğuna inanmaktadırlar.

Yapılan analizler sonucunda futbol kulübü yöneticilerine çeşitli önerler getirilmektedir. Bunlardan ilki stadyumlara gelen taraftarların davranışlarının takip edilerek güvenliği etkileyecek davranışlara yönelik önlemlerin alınması daha fazla sayıda kadınların stadyumlara gelmesini sağlayacağı düşünülmektedir. Stadyuma gelen erkek taraftarların eşlerini, çocuklarını ve kız arkadaşlarını getirebilmeleri aynı zamanda daha fazla erkek taraftarın da stadyumlara çekilmesini sağlayacaktır. Bu bağlamda kadınlar futbol kulüpleri için önemli bir hedef kitledir ve kadınların kaygı ve beklentilerine uygun oluşturulan stadyum atmosferinin kulüplerin gelirlerini daha da çok artıracağına inanılmaktadır.

Araştırmanın bazı kısıtlamaları bulunmaktadır. Örneklemin kısmen yetersiz olması bulguların genellenmesi açısından kısıt oluşturmaktadır. Buna ek olarak araştırmanın yapıldığı sürede federasyonun bu uygulaması bir kaç büyük futbol kulübüne uygulandığından orta ve küçük kulüp seyircileri örnekleme dahil edilmediğinden sonuçları genelleştirmek doğru olmayabilir. Çok büyük bir endüstri olan futbol sektörüne yönelik daha çok sayıda araştırmalar yapılmalıdır. Örneğin Federasyon'un uygulamasından yararlanan çocuklara yönelik de araştırmaların yapılması endüstrinin geleceğine yönelik öngörülerde bulunmak açısından yararlı olacağı düşünülmektedir. Ayrıca aynı araştırma hem kadınlar hem de erkeklere yapılarak uygulamanın erkekler üzerindeki etkisiyle kadınlar üzerindeki etkisi karşılaştırılabilir. Federasyonun uygulamasından yararlanmayan kadınları kapsayan

örneklemle de benzeri araştırmalar yapılabilir. Örnekleme uygulamadan yararlanmayan kadınlar da dâhil edilerek iki grup arasındaki farkların da incelenmesi farklı bulguların elde edilmesini sağlayacağı düşünülmektedir.

\section{Kaynakça}

Berument, H. \& Yücel, E. M. (2005). Long live Fenerbahce: The production boosting effects of football. Journal of Economic Psychology, 26, 842-861.

Clowes, J. \& Tapp, A. (2003). Looking through the hourglass of fan segmentation: Research findings and marketing implications for live spectator sports. International Journal of Sport Marketing and Sponsorship, March/April, 5773.

Gwinner, K. \& Swanson, S.R. (2003). A model of fan identification: Antecedents and sponsorship outcomes. Journal of Services Marketing, 17/3, 275-294. 
Yalova Sosyal Bilimler Dergisi

Hill, B. \& Green, B. C. (2000). Repeat attendance as a function of involvement, loyalty, and the sportscape across three footbal contexts. Sport Management Review, 3, 145-162.

James, J.D. \& Ross, S. D. (2004). Comparing sport motivations across multiple sports. Sport Marketing Quarterly, 13, 17-25.

Kenneth, A.H., Bristol, T. \& Bashaw, E.R. (1999). A conceptual approach to classifying sports fans. Electronic Journal.

Kotler, P. \& Armstrong, G. (2008). Principles of marketing (10. ed.). London: Pearson Prentice Hall.

Lough, N. L. \& Kim, A. (2004). Analysis of sociomotivations affecting spectator attendance at women's professional basketball games in South Korea. Sport Marketing Quarterly, 13, 35-42.

Mehus, I., (2005). Sociability and excitement motives of spectators attending entertainment sport events: spectators of soccer and ski-jumping. Journal of Sport Behavior, 28/4, 333-350.

Mucuk, İ. (2010). Pazarlama ilkeleri (17. Baskl). İstanbul: Türkmen Kitapevi.

Ross, S.D., (2006). A conteptual framework for understanding spectator-based brand equity. Journal of Sport Management, 20, 22-38.

Richardson, B. \& O’Dwyer, E. (2003). Football supporters and football team brands: A study in consumer brand loyalty. Irish Marketing Review, 16/1, 43-53.

Türkmen, M., Kaldırımc1, \& İmamoğlu, M. H. (1998). Türk spor kültüründe kadın unsuru. I. Spor Kongresi, 16-18 Mart, Erzurum/Türkiye, 24-30.

Wann, P. \& Pierce, S. (2003). Measuring sport team indetification commitment: An empirical comparison of the sport spectator indetification scale and the psychological commitment to team scale. North American Journal of Psychology, 5/3, 365-372.

Yoshida, M., James, J. D. \& Cronin, J. J. (2013). Sport event innovativeness: Conceptualization, measurement, and its impact on consumer behavior. Sport Management Review, 16, 68-84.

http://www.futbolekonomi.com/index.php?option=com_content $\&$ view=article $\&$ id $=20$

$98:$ kadn $\% 20$ taraftarar $\&$ catid $=265:$ laleorta $\&$ Itemid $=58 \% 20, \% 20$

(Erişim:11.09.2012).

\section{Ölçekte kullanılan ifadeler.}

1 Maç bilet fiyatlarını yüksek buluyorum.

2 Maç bilet fiyatları yüksek olduğundan müsabakaları izlemek için stadyuma gitmiyorum. 
3 Maç bilet fiyatları daha düşük olsa stadyuma maç seyretmek için giderim.

4 Futbola ilgi duyuyorum.

5 Futbol müsabakalarının sonuçlarını takip ediyorum.

6 Futbol oyunuyla ilgili yeterince bilgiliyim.

7 Taraftarı olduğum takımın başarısı benim için önemli.

8 Taraftarı olduğum takımın oynadığı müsabaka sonuçlarını takip ediyorum.

9 Taraftarı olduğum takımın şampiyon olmasını çok istiyorum.

10 Futbol müsabakalarını stadyumda seyretmek konforlu değil.

11 Futbol müsabakalarını stadyumda seyretmek keyifli değil.

12 Futbol müsabakalarını stadyumda seyretmek rahat değil.

13 Futbol müsabakalarında taraftarların çıkarttığı olaylar beni endişelendiriyor.

14 Müsabaka seyretmek için stadyuma gitmeyi güvenli bulmuyorum.

15 Stadyumlardaki güvenlik önlemlerini yetersiz buluyorum.

16 Seyirciler arasında bayların olmaması stadyuma giderek müsabakayı izlememde önemli etkendir.

Bay seyircilerin küfürlerini duymak istemediğim için bu uygulama stadyuma gitmem için firsat oldu.

Bay seyircilerin taşkınlıkları olmadığından bu uygulama stadyuma gitmem için firsat oldu.

19 Çevremdeki insanlar kadınların müsabaka seyretmek için stadyuma gitmelerini hoş karşılamıyorlar.

20 Çevremdeki insanlar kadınların müsabaka seyretmek için stadyuma gitmelerini doğru bulmuyorlar.

21 Çevremdeki insanlardan eleştiri alamamak için müsabaka seyretmek için stadyuma gitmiyorum.

22 Sosyal faaliyetler yapmak için yoğunluğumdan dolayı yeterince zaman bulamiyorum.

23 Futbol müsabakalarını stadyumda izlemek keyifli.

24 Futbol müsabakalarını stadyumda izlemek heyecan verici.

25 Futbol müsabakalarını stadyumda izlemek daha eğlenceli.

26 Arkadaş çevrem bu uygulamadan yararlanmamda etkili oldu.

27 Stadyuma giderek maç izlemem arkadaşlarımla ortak bir faaliyet yapmış 
olmam için önemli bir etken oldu.

28 Stadyuma giderek müsabaka izlemem arkadaşlarımla birlikte zaman geçirmem için önemli bir etken oldu.

29 Bu uygulama sayesinde stadyumda maç izlemenin keyifli olduğunu fark ettim.

Bu uygulama sayesinde stadyumda müsabaka seyretmenin iyi bir sosyal aktivite olduğunu anladım.

31 Bu uygulama sayesinde normal zamanlarda da müsabaka seyretmek için stadyuma gitmeye karar verdim.

32 Bu uygulama sayesinde bir takımın taraftarı olmanın keyifli olduğunu anladım.

33 Bu uygulamadan yararlanmam taraftarı olduğum takımın müsabakalarını stadyumda seyretmenin eğlenceli olduğunu fark etmeme yaradı.

34 Bu uygulama sayesinde normal zamanlarda da bilet alarak müsabaka seyretmek için stadyuma gidebilirim.

35 Bu uygulama kadınların futbola daha çok ilgi duyması gerektiğini düşünmemi sağladi.

36 Bu uygulama kadınların futbola daha fazla zaman ayırması gerektiğini düşünmemi sağladı.

37 Bu uygulama sayesinde arkadaşımla/eşimle futbol müsabakalarına gitme kararı aldım.

38 Bu uygulamanın devam etmesini istiyorum.

39 Bu uygulamayı kadınlara karşı pozitif ayrımcılık olarak görüyorum.

40 Bu uygulamayı destekliyorum.

41 Bu uygulamayı kadınlara yapılmış (olumsuz anlamda) ayrımcılık olarak görüyorum.

42 Bu uygulamayı kadınlara yapılmış hakaret olarak görüyorum. 